\title{
KRITIK TEORI KEAGENAN DALAM ARTIKEL AKUNTANSI: KONTEKS KE-INDONESIA-AN
}

\author{
Andi Sri Wahyuni \\ Politeknik Negeri Ujung Pandang \\ andisriwahyuni@poliupg.ac.id
}

\begin{abstract}
Abstrak: Penelitian ini untuk mengkritisi penggunaan teori keagenan dalam berbagai penelitian akuntansi di Indonesia. Sebagai upaya meninjau ulang dan memberikan solusi atas kritik tersebut, pendekatan kualitatif digunakan dengan meminjam pendekatan kritik sastra sebagai pisau analisis. Untuk menganalisis konteks yang berada di sekitar riset-riset tersebut ketika dikerjakan dan dipublikasikan, penulis menggunakan artikel Anafiah, et al (2017) sebagai objek penelitian. Hasil analisis menunjukkan, teori keagenan yang selama ini menjadi tonggak raksasa dalam pembangun hipotesis-hipotesis penelitian akuntansi pasar modal tidaklah relevan dengan konteks ke-Indonesia-an. Ini karena menggeneralisasikan kondisi pada setiap negara dalam menginduksi argumen menjadi sebuah hipotesis merupakan penarikan kesimpulan awal yang semenamena dengan mengesampingkan konteks yang terjadi di Indonesia. Dengan demikian, adalah hal yang kiranya tidak relevan menggunakan teori keagenan jika berada dalam lingkup objek penelitian Indonesia, tanpa dikunci oleh variabel kontrol yang jelas, dalam hal ini kondisi masyarakat Indonesia yang pola pikirnya telah banyak dibentuk oleh rezim orde baru.
\end{abstract}

Kata Kunci: Riset Akuntansi Pasar Modal, Teori Keagenan, Orde-baru Indonesia, Kritik sastra.

\section{PENDAHULUAN}

Riset terkait akuntansi, khususnya yang menggunakan teori keagenan (agency theory) sebagai pijakan, tak henti-hentinya bertebaran memenuhi ruang-ruang publikasi penelitian akuntansi hingga kini. Ada dua nama yang dapat dirujuk sebagai penulis yang publikasi risetnya masih terus hidup dalam napas riset-riset akuntansi Indonesia dengan dasar teori keagenan. Mereka adalah Jensen dan Meckling (1976).

Teori keagenan yang dikemukakan oleh Jensen dan Meckling (1976) ini memberikan batas hak dan kewajiban yang jelas antara seorang pemilik dan pengelola perusahaan. Teori ini menempatkan seorang pengelola sebagai pihak yang diawasi. Dengan kalimat lain, teori ini dibangun atas dasar ketidakpercayaan. Merujuk pada penelitian Zogning (2017), dapat dipastikan bahwa teori ini lahir dari postulat yang dikemukakan oleh Adam Smith. Postulat yang menasbihkan manusia hidup di atas tanah yang penuh dengan kompetisi dan perlombaan, dan sebab itu berusaha sendiri-sendiri dan mempertahankan kepemilikannya sendiri-sendiri. 
Ketika Jensen dan Meckling (1976) menuliskan hal tersebut, manusia dipandang sebagai makhluk yang tidak bisa dipercaya sebab masing-masing individu hanya akan melakukan sesuatu untuk kepentingannya. Ada banyak penelitian yang berdatangan setelah postulat tersebut dikemukakan, yang kesemuanya membuktikan bahwa pernyataan itu sungguh keliru. Wahyuni dan Nentry (2017) misalnya, membeberkan kisah seorang pengusaha kecil-kecilan di Makassar yang mengedepankan asas saling mengasihi dengan para pelanggannya dalam lingkup bisnis yang didirikannya. Demikian pula Wright (2011) menyatakan bahwa selain motif ekonomi, ada banyak motif yang menggerakkan manusia untuk berkumpul dan berinteraksi dengan sesamanya, seperti karena kebiasaan, atau karena basis moral.

Karena ketidakkonsistenan tersebut, teori keagenan dianggap tidak lagi relevan digunakan dalam penelitian akuntansi, utamanya dalam konteks Indonesia. Hal ini karena Indonesia memiliki budaya yang berbeda dengan dunia barat, di mana rasa kekeluargaan masih sangat kental dan senantiasa terbawa dalam interaksi sosial masyarakat, termasuk dalam interaksi bisnis di perusahaan (Sitorus, 2015).

Salah satu bentuk nyata nilai kekeluargaan yang masih begitu melekat adalah konsep paternalistik dalam hubungan yang tua dan muda. Konsep ini bisa dilacak keberadaannya dari penelitian Shiraishi (2009) yang memaparkan warisan orde baru berupa hubungan Bapakisme dalam konteks bernegara hingga ke lembaga terendah berupa keluarga. Hal ini jelas menetes ke bawah hingga ke lembaga berupa perusahaan.

Dengan demikian, konsep teori keagenan yang melihat hubungan pemilik dan pengelola perusahaan-perusahaan yang beroperasi di Indonesia, semata hubungan bisnis tidaklah tepat. Penelitian ini hadir untuk mengkritisi ruang kosong yang luput diamati oleh peneliti-peneliti akuntansi yang menggunakan teori keagenan sebagai dasar teori penelitian yang telah dikerjakan dan dipublikasikan selama ini. Selain mengkritisi, penelitian ini juga sebagai upaya menutup ruang kosong tersebut agar teori yang digunakan dalam penelitian akuntansi lebih relevan dan dapat diandalkan di masa mendatang.

\section{METODE PENELITIAN}

Penelitian ini menggunakan artikel Anafiah, et al (2017) sebagai objek yang dikritisi dengan menggunakan kritik sastra sebagai alat analisis. Kritik sastra digunakan untuk menganalisis konteks suatu kata atau frasa ketika dimasukkan dalam potongan kalimat atau frasa sebuah karya tulis. 
Penggunaan satu artikel untuk menganalisis kondisi yang mempengaruhi pandangan penulisnya dan memahami berbagai pengaruh eksternalnya adalah pendekatan kritik sastra yang hampir belum pernah digunakan dalam penelitian akuntansi di Indonesia. Terlebih pada bidang riset akuntansi yang masih menjadikan pendekatan kuantitatif-positivistik sebagai primadona. Namun, usaha meminjam dan menggunakan karya sastra sebagai alat analisis telah pernah dicoba oleh Wahyuni (2015) dalam melakukan penelitian di bidang akuntansi manajemen di Indonesia. Sementara itu, dalam berbagai publikasi skala internasional, penggunaan karya seni dan sastra sebagai alat analisis untuk penelitian akuntansi bukanlah hal yang baru (Dimnik dan Felton (2006); Evans, 2009; Evans dan Fraser, 2012; James 2008, 2009; Schuler 1998). Di sisi lain pula, disiplin ilmu yang serumpun dan terhimpun dalam fakultas yang sama ${ }^{1}$, manajemen misalnya, sudah pernah meminjam kritik sastra dalam mengkaji manajemen sumber daya manusia pada sebuah novel (Jalil dan Kadir, 2012).

Sebelum akhir tahun 60-an, interpretasi atas sebuah karya sastra dengan mempertimbangkan faktor-faktor luar, sesungguhnya adalah kegiatan yang diharamkan. Namun setelahnya, muncul pandangan bahwa interpretasi tidak hanya dikaitkan dengan kaidah-kaidah umum bahasa yang digunakan penulis, tapi juga segala hal yang berkaitan dengan pandangan dan sikap hidup pengarang seperti keadaan, kepercayaan, lingkungan budaya zaman, keadaan masyarakat, nilai-nilai dan sebagainya. Berangkat dari pernyataan yang dimunculkan oleh Damono (2006) tersebut, secara otomatis, lingkungan dan ideologi yang sedang mendominasi lingkungan penulis, akan banyak berpengaruh pada karya yang dibuat (ditulis). Maka, dengan menggunakan kritik sastra sebagai sebuah pendekatan, penulis dapat mengurai segala hal yang berkaitan dengan lingkungan dan kecendrungan paradigma, bahkan ideologi yang digunakan oleh penulis riset yang karyanya sedang dianalisis dan dikritik.

Selanjutnya, kritik atas sebuah karya sastra, sebagaimana dijelaskan juga oleh Damono (2006), adalah hasil dari uraian yang rinci dan hati-hati atas hubungan-hubungan yang rumit antara unsur-unsur yang ada dalam karya sastra, terutama yang terkait dengan ambiguitas. Maka selaras dengan itu, penelitian ini juga menggunakan karya Anafiah, et al (2017) untuk mengurai teori yang digunakan berupa teori keagenan, sebagai bentuk 'hati-hati atas hubungan-hubungan yang rumit' dan 'terutama menyangkut ambiguitas' atas teori keagenan yang digunakan sebagai dasar teori penelitian dalam riset akuntansi.

\footnotetext{
${ }^{1}$ Jurusan Akuntansi dan Jurusan Manajemen dalam banyak institusi dan atau perguruan tinggi di Indonesia dikelompokkan dalam satu fakultas bersama, Fakultas Ekonomi dan Bisnis.
}

Jurnal Akuntansi dan Teknologi informasi (JATI) Vol. 12 No. 2 September 2018 
Konsep hubungan antara pemilik dan pengelola perusahaan di Indonesia, sesungguhnya terbentuk dan terbangun di masyarakat Indonesia dengan banyak dipengaruhi peninggalan pola pikir orde baru yang sengaja dibangun oleh Soeharto sebagai Bapak Tertinggi dalam politik Indonesia. Ini merupakan hasil penelitian etnografer Jepang, Saya Sasaki Shiraishi, yang dimulai pada tahun 1989. Bagi saya, selama ini para peneliti akuntansi yang menggunakan teori keagenan ketika melihat hubungan antara pemilik dan pengelola perusahaan telah mengabaikan konteks relasi kuasa semacam ini. Karena itu pula, ulasan terhadap penelitian dan kajian teori keagenan jarang dibawa ke pertanyaan, mengapa dan untuk apa konsep tersebut dibentuk dalam roda perputaran produksi suatu perusahaan. Penelitian ini berusaha hadir untuk melengkapinya.

Adapun artikel Anafiah, et al (2017) yang dipublikasikan di Jurnal Akuntansi dan Keuangan Indonesia (JAKI) dipilih sebagai objek analisis disebabkan karena pertimbangan keterbaruan riset dan relevansi data. JAKI adalah wadah publikasi artikel akuntansi dan keuangan ilmiah yang memiliki citra prestisius di Indonesia, dengan terakreditasi Science and Technology Index (SINTA) dengan level S2 dan memiliki impact factor 4,33. Untuk bidang akuntansi, level S2 merupakan level tertinggi dalam akreditasi jurnal akuntansi dan angka impact factor yang dimiliki JAKI juga merupakan angka tertinggi untuk jurnal akuntansi di Indonesia-merujuk pada laman resmi SINTA keluaran Kementerian Riset, Teknologi, dan Pendidikan Tinggi (Ristekdikti) pada tahun $2017^{2}$.

Sederhananya, secara simbolik jurnal akuntansi yang terakrediasi Science and Technology Index (SINTA) merupakan representasi dari berbagai penelitian akuntansi di Indonesia yang sudah memenuhi standar-standar publikasi ilmiah yang dikeluarkan oleh Ristekdikti. Dengan demikian, artikel yang berhasil lolos pada penerbit jurnal bereputasi sekelas JAKI tentulah dapat dianggap sebagai riset-riset berkualitas dalam bidang akuntansi yang ada di Indonesia.

Bahkan, oleh beberapa kalangan, memublikasikan jurnal dengan skala internasional dianggap lebih mudah dibanding memublikasikannya di jurnal nasional terakreditasi SINTA. Seorang dosen senior di tempat yang sama dengan peneliti mengabdi, bernama $\mathrm{Nurna}^{3}$, yang baru saja menyelesaikan pendidikan doktoralnya pada tanggal 26 Agustus 2019, harus puas dengan status kelulusan 'Memuaskan'. Status 'Cum laude’ tidak dapat diraih karena tidak ada artikel publikasi nasional yang terakreditasi SINTA berhasil untuk diterbitkan. Akan tetapi,

\footnotetext{
${ }^{2}$ Diakses dari laman http://sinta2.ristekdikti.go.id/journals/ pada 07 Nopember 2019.

${ }^{3}$ Nama disamarkan untuk kepentingan responden.

Jurnal Akuntansi dan Teknologi informasi (JATI) Vol. 12 No. 2 September 2018
} 
dosen tersebut malah mampu menghasilkan tiga publikasi di jurnal internasional. Oleh dosen yang bersangkutan, beberapa hari setelah ujian, bercerita kepada penulis,

"lebih susah terbit di jurnal nasional yang terakreditasi ketimbang internasional. Hal ini karena di nasional banyak antrian, banyak mahasiswa yang harus menerbitkan artikelnya karena aturan. Apalagi penerbit jurnal yang terakreditasi juga tidak banyak."

Justifikasi tersebut semakin kuat berdasarkan penuturan seorang rekan dosen lain bernama $\mathrm{Nafsah}^{4}$ yang bercerita tentang sulitnya proses terbit artikelnya di salah satu jurnal nasional terakreditasi SINTA. Setelah tiga kali revisi yang menghabiskan waktu lebih dari enam bulan, artikelnya masih juga belum terbit. Proses yang ketat ini meniscayakan standar yang tinggi terhadap kualitas artikel-artikel yang akan diterbitkan oleh tersebut, bukan proses yang serampangan.

Demikianlah alasan mengapa penelitian ini meminjam salah satu artikel dalam bidang riset akuntansi yang ditulis Anafiah, et al (2017) dan berhasil diterbitkan di JAKI sebagai objek untuk analisis literatur dengan meminjam analisis kritik sastra. Artikel yang dipilih, mempertimbangkan syarat keterbaruan dan data-data yang dirujuk pada artikel tersebut, juga relevan untuk menjelaskan fokus penelitian ini. Fokus penelitian yang dimaksud adalah penggunaan teori keagenan dalam sebuah perusahaan dalam riset akuntansi di Indonesia.

Akhirnya, pandangan dari Anafiah, et al (2017) dalam membangun konsep pengontrolan para pemilik kepada pengelola perusahaan sebagai pondasi teori risetnya akan menjadi interpretasi bagaimana konsep teori keagenan dipahami oleh periset lain di Indonesia secara umum. Dalam hal ini, artikel Anafiah, et al (2017) dipahami sebagai wakil dari risetriset sejenis yang menggunakan teori yang sama.

\section{TEORI METODOLOGIS : KRITIK SASTRA SEBAGAI 'ANAK' BARU METODE PENELITIAN AKUNTANSI}

Berangkat dari latar belakang dan tujuan yang telah dipaparkan pada sub-bab sebelumnya, pemilihan pisau analisis dalam proses penelitian ini dengan sengaja menggunakan kritik sastra. Alat analisis ini dipilih bukan semata karena kebaruan atau keunikan, akan tetapi sesuai dengan tujuan penelitian untuk memahami secara menyeluruh karya Anafiah, et al (2017), dalam bentuk apa pun itu, baik pemahaman terhadap kondisi internal maupun eksternalnya. Sebagaimana penegasan dari Evans dan Fraser (2012) dan Bandel (2013) yang menyatakan bahwa tujuan dari analisis kritik sastra adalah membantu

${ }^{4}$ Nama disamarkan untuk kepentingan responden.

Jurnal Akuntansi dan Teknologi informasi (JATI) Vol. 12 No. 2 September 2018 
peneliti memahami konteks suatu tulisan secara kompleks, dengan memerhatikan kondisi eksternal maupun internal saat tulisan dikerjakan dan dipublikasikan.

Dalam kritik sastra sendiri, beberapa pendekatan dapat digunakan. Pendekatan sosiologi dan budaya pernah digunakan oleh Sirimorok (2008) dalam mengkritik karya-karya Andrea Hirata. Kemudian pendekatan feminis pernah digunakan oleh A-Ma'ruf (2003). Pada tahun-tahun selanjutnya, muncul pendekatan baru yakni Kritik Tanggapan Pembaca yang ditawarkan Damono (2006). Untuk keperluan penulisan riset ini, penulis menggunakan pendekatan sosio-politik ke-Indonesia-an. Hal ini karena pendekatan tersebut cukup relevan dengan hasil penelitian Shiraishi (2009) tentang pembentukan citra keluarga di Indonesia dengan mengkaji kondisi sosial dan politik pada masa kepemimpinan Soeharto.

Sebagaimana telah ditegaskan oleh Dimnik dan Felton (2006), penggunaan karya fiksi dapat menguntungkan peneliti untuk memahami kajian akuntansi dalam konteks sosial di mana penelitian tersebut dilakukan. Sederhananya, kata Evans dan Fraser (2012), karya sastra menjadi media untuk memahami kondisi budaya, ekonomi hingga politik sesuai dengan konteks penulisan karya tersebut. Lebih lanjut, kritik sastra merupakan pendekatan yang mengelaborasi berbagai sudut pandang untuk kemudian menjelaskan mengapa seorang penulis sampai pada penilaian tertentu (Bandel, 2013). Kritik sastra tidak semata tentang bagus tidaknya suatu karya, tapi mengekspilisitkan apa yang implisit—ideologi yang dibawa oleh penulis, misalnya (Bandel, 2013). Dengan meminjam pendekatan tersebut, artikel Anafiah, et al (2017) dianalisis dan dikritik untuk mewakili pandangan periset dan atau penulis lain dalam menggunakan teori keagenan, juga berbagai kondisi yang berpengaruh secara internal maupun eksternal di sepanjang proses penulisan hingga penyebarluasan artikel tersebut.

Di sini lah letak pentingnya penelitian ini. Kondisi sosial dan politik yang mempengaruhi teori keagenan, mau tidak mau, harus dipertimbangkan oleh para periset akuntansi dalam menggunakan teori keagenan dalam konteks Indonesia. Ada pun penjelasan lebih lanjut terkait alasan pemilihan artikel dan selanjutnya metode dalam penulisan artikel ini, dijelaskan secara memadai dalam sub-bab berikut.

\section{PEMBAHASAN}

\section{Keluarga Indonesia dalam Sosio-Politik.}

Shiraishi (2009), seorang peneliti Jepang pernah mencari asal-usul terbentuknya kata 'keluarga' di Indonesia. Setiap bangsa, menurut Shiraishi (2009), memiliki cara dan gaya 
tersendiri dalam membangun kebangsaannya, sebab pencitraan suatu bangsa selalu berubah senapas dengan dinamika sejarahnya.

Terlebih, Freire (2008) pernah menegaskan bahwa hubungan orangtua-anak dalam keluarga, secara umum mencerminkan kondisi kebudayaan obyektif dari struktur sosial sekitarnya. Dengan demikian, bagaimana hubungan yang terjadi antar kelas dalam suatu masyarakat, dapat dilihat melalui bagaimana hubungan yang terbentuk dalam lingkup keluarga di dalam masyarakat tersebut secara umum.

Demi memahami keluarga Indonesia secara utuh, menurut Shiraishi (2009:7), perlu kiranya bersifat hati-hati dengan melakukan diskursus-diskurus. Hal ini untuk menghindari sikap pasrah, menerima begitu saja pengertian yang telah diterima umum, seperti bapak, ibu dan anak. Pengertian-pengertian tersebut, lanjut Shiraishi (2009), merupakan hasil konstruksi budaya yang memiliki sejarahnya masing-masing.

Gambaran terkait bagaimana budaya kepemilikan dan kontrol dalam bentuk kepatuhan yang paternalistik dibentuk dalam masa orde baru dapat dimulai dengan memahami hasil penelitian Shiraishi (2009:1) dengan menukilkan perkataan Soeharto ${ }^{5}$ sebagai berikut:

"Di mata saya tidak ada emas, juga tidak ada anak ${ }^{6}$ yang tidak saya senangi. Tidak ada. Semua mereka itu, dalam tugas dan bidangnya masing-masing, mempunyai kepercayaan yang sama dari saya. Semuanya pembantupembantu dekat saya sesuai bidangnya masing-masing...”

Dalam kutipan tersebut, Soeharto adalah bapak dan pembantu-pembantu (para menteri) adalah anak-anak Soeharto. Citra sebagai seorang bapak secara tersurat sengaja dibentuk dari kutipan tersebut.

Selama 32 tahun berkuasa, Soeharto menempatkan diri sebagai Bapak Tertinggi (Supreme Father) bagi para bawahan (pembantu) dan rakyatnya (Shiraishi, 2009). Dalam hubungan tersebut, hanya ada hubungan antara bapak/ibu dan anak di mana anak harus patuh kepada bapak/ibu, tidak boleh mengkritik. Kegiatan melawan atau menentang adalah tercela, sekali pun itu adalah perbuatan yang tidak sesuai dengan etika dan moral yang dipahami anak (Shiraishi, 2009). Kondisi semacam ini dengan berani digambarkan oleh Damayanti (2012) sebagai "reinkarnasi masa kerajaan dan kolonialisme".

\footnotetext{
${ }^{5}$ Dikutip dari buku Soeharto. Soeharto: Pikiran, Ucapan, dan Tindakan Saya: Otobiografi. Kalimat-kalimat tersebut dipaparkan kepada G. Dwipayana dan Ramadhan K.H. (Jakarta: PT. Citra Lamtoro Gung Persada, 1989), hlm. 429.

${ }^{6}$ Sengaja dicetak tebal untuk mengidentifikasi frase-frase yang akan diuraikan.
} 
Penguasa orde baru membentuk bangsa tak ubahnya sebuah keluarga yang harmonis - meski dengan pola-pola kekerasan. Jika demikian, mungkinkah 'si anak' melawan 'bapak'-nya?

"Kendati punya pikiran dan pendapat sendiri, mereka diharapkan cukup matang untuk mengendalikan diri dan senantiasa patuh terhadap petunjuk dan perintah Soeharto',

demikian tulis Shiraishi." (2009:122)

Sebagai balas jasa, bapak/ibu akan memberikan perlindungan dan rasa aman bagi anak-anaknya. Perlindungan yang diberikan semacam ini kemudian menjadi amat rentan berubah wujud menjadi nepotisme sebagaimana orang-orang terdekat Soeharto mendapatkan aksebilitas 'emas'. "They can claim protection, gifts and help when needed, but they must listen...”, tulis Efferin dan Hopper (2007) menggambarkan hubungan bapak-anak tersebut. Meskipun Efferin dan Hopper (2007) lebih spesifik meneliti Budaya Tiong-Hoa, namun objek penelitian yang digunakan masih merupakan perusahaan yang beroperasi di Indonesia dan hasil analisis keduanya tetap dapat menggambarkan bagaimana kekuatan hubungan anakbapak bekerja di perusahaan-perusahaan yang ada di Indonesia.

Selanjutnya, apa yang terjadi dengan 'keluarga nasional' semenjak orde baru dan apa yang dilakukan rakyat Indonesia terhadap tradisi 'keluarga nasional' adalah dua hal yang saling berhubungan. Tingkah dan laku antara anak-anak dan bapak menjadi terpola dalam satu lembaga besar. Lembaga itu bernama Indonesia.

Pola tersebut menetes ke bawah, membasahi pemerintah tingkat kota dan provinsi. Penelitian Damayanti (2012) membuktikan keberadaan hubungan bapak-anak emas ini di salah satu instansi pemerintah yang ada di Indonesia. Lembaga pendidikan dan perusahaanperusahaan pun tidak luput dari tetesan pola hubungan tersebut. Perusahaan, yang bahkan tidak berjalan dalam rel pemerintahan, akhirnya menjadikan tata-krama bapak dan anak untuk mewujudkan 'ketertiban' dan 'keamanan' dalam beroperasi.

Pernyataan dari Ruth McVey, salah seorang tentang Indonesia dari Cornell University (Roosa, 2008), yang disalin-tempel Shiraishi (2009:122) berikut, cukup baik menjelaskan konsep keluarga yang merambah hingga ke berbagai lembaga di Indonesia.

"Organisasi suatu kelompok atau pemerintah dan masyarakat dalam sebuah "dasar kekeluargaan" merupakan tema yang terus berlanjut dalam kajian tentang Indonesia modern. Hal ini digunakan untuk membenarkan paternalisme-sering diledek sebagai bapak-isme-dalam pemerintahan atau hubungan sosial dan untuk mencegah berbagai tantangan dari dalam terhadap kepemimpinan..." 
Menjadi benarlah pernyataan tersebut dengan melihat pengaruh hubungan bapak-anak yang terjadi pada perusahaan-perusahaan besar di masa orde baru. Perusahaan-perusahaan yang ada, selain menerapkan pola hubungan bapak-anak di dalamnya, juga terhubung dengan bapak negara secara langsung. Beberapa perusahaan di antaranya, seperti ditulis Shiraishi, adalah Bank Duta, PT Citra Sari Makmur, dan PT Sumber Tani Agung.

Hal tersebut berimbas pada interaksi yang terjadi dengan seluruh pemegang kepentingan dalam perusahaan. Terlebih jika memang pada dasarnya perusahaan tersebut adalah perusahaan dengan basis kepemilikan keluarga-biasanya berupa kepemilikan saham mayoritas.

Toleransi bapak diwujudkan dengan berbagai pemakluman kinerja 'anak'. Datang ke kantor terlambat atau menggunakan kendaraan dinas perusahaan untuk keperluan pribadi adalah dua tindakan yang tidak menyimpang sebab memang demikianlah tugas 'bapak' untuk memberikan fasilitas kepada 'anak'. Toleransi yang keliru ini dipelintir menjadi sebuah bentuk kasih-sayang 'bapak' kepada 'anak', pimpinan kepada bawahan.

Selanjutnya, pola hubungan bapak-anak menjadi rujukan oleh banyak pemimpin, bagaimana seharusnya kepemimpinan ideal itu dijalankan. Bercermin dari kedigdayaan dan lamanya Soeharto memimpin dengan gaya 'bapak-anak', terimajinasikan sempurna oleh masyarakat Indonesia pada masa orde baru sebagai bentuk kepemimpinan yang dapat menjaga harmonisasi hubungannya dengan bawahan. Dalam konteks riset akuntansi, hubungan tersebut tergambar antara pemilik saham dengan pihak manajemen.

Membaca uraian-uraian Shiraishi (2009) tersebut, konsep teori keagenan yang selama ini digunakan oleh para peneliti akuntansi tampak pucat. Konsep keluarga yang didengungkan selama ini, mungkinkah buta relasi kuasa?

\section{Teori Keagenan dalam Hubungan Paternalistik.}

Alpanya Anafiah, et al (2017) dan para penelitian lain yang menggunakan teori keagenan untuk mempertimbangkan relasi antara pemilik dan pengelola dalam lingkar struktur perusahaan di Indonesia, bagi penulis, adalah satu kelemahan logika dalam artikelartikel mereka masing-masing. Hal ini dengan mengingat bahwa rujukan utama mereka masih bertumpu pada teori-teori "barat" yang, sekali lagi, memiliki konteks lingkungan bisnis masing-masing.

Para peneliti yang membangun hipotesisnya terjebak dengan teori keagenan (teori agency) yang dicetuskan oleh Jensen dan Meckling (1976). Hal ini jelas meminggirkan 
pertanyaan mendasar, apakah teori semacam ini layak dan tepat untuk digunakan dalam konteks Indonesia?

Pada artikel tersebut, Anafiah, et al (2017) jelas tidak sungkan menggunakan teori keagenan yang dicetuskan Jensen dan Meckling (1976) sebagai landasan pembentuk hipotesis-hipoetsis yang dibangun kemudian. Riset-riset semacam ini adalah jenis kuantitaif, tentu. Teori keagenan dengan jelas tersurat pada bagian rerangka teoritisnya, seperti terpapar pada tulisan berikut :

In a dispersed ownership structure agency conflict commonly occurs as a consequence of management's discretions that are not in accordance with shareholders' interests (Jensen and Meckling 1976).

Tidak sungkan-sungkan Anafiah, et al (2017) mengutip teori keagenan Jensen dan Meckling (1976) pada paragraf pertama review literaturnya. Menengok ke artikel lain milik Putri dan Diyanty (2014) : "Menurut teori keagenan (Jensen dan Meckling, 1976), konflik keagenan yang terjadi bergantung pada pola kepemilikan perusahaan."

Selanjutnya, pada artikel lain lagi milik Ulupui, et al. (2014) :

"Kompensasi yang diberikan kepada para eksekutif merupakan fenomena yang menarik untuk diteliti. Sejarah riset tentang kompensasi yang modern dimulai pada awal tahun 1980-an, yaitu munculnya teori keagenan yang pertama kali diutarakan oleh Berle and Means (1932) yang selanjutnya diformalkan oleh Jensen dan Meckling (1976) (dalam Murphy, 1998).”

Penggunaan kutipan pada bagian pendahuluan dan awal sub-bab memiliki nilai lebih dibanding kutipan-kutipan lain yang digunakan dalam naskah artikel yang sama. Para penulis dan atau peneliti secara hati-hati memilih nama-nama pendahulu riset dengan fokus kajian yang sama untuk membangun 'state of the art' artikel mereka. Dengan demikian, pada dua artikel di atas, Jensen dan Meckling (1976) tidak hanya membantu penulis riset tersebut untuk membangun hipotesis, akan tetapi menjadi rujukan utama yang kemudian dituangkan dalam pendahuluan artikel, bahkan sebagai pembuka di paragraf pertama.

Namun, perlu diingat bahwa dua penulis barat ini, Jensen dan Meckling (1976), jelas menggeneralisasikan kondisi pada setiap negara dalam menginduksi argumen mereka menjadi sebuah teori. Baik Jensen, maupun Meckling, jelas tidak pernah menyinggung konteks negara Indonesia di artikelnya sebagai sebuah pertimbangan untuk merumuskan teori mereka. Hal ini berkebalikan dengan apa yang ditemukan oleh Hofstede (1983), seorang peneliti budaya dan organisasi, tepat tujuh tahun setelah teori keagenan tersebut dicetuskan. Hofstede (1983), 
dengan meneliti berbagai dimensi budaya dari 50 negara yang berbeda dan menyebarkan sebanyak 116.000 kuesioner menghasilkan sebuah kesimpulan bahwa budaya organisasi tiaptiap negara akan berbeda bergantung di mana perusahaan dijalankan.

Dengan demikian, adalah hal yang kiranya tidak relevan menggunakan teori keagenan dari keduanya jika berada dalam lingkup objek penelitian Indonesia, tanpa variabel kontrol yang jelas. Terlebih lagi jika menengok beberapa penelitian sebelumnya yang menyatakan tidak relevannya teori keagenan digunakan untuk konteks negara (Asechemie, 1997; Hopper, et al., 2017) maupun pemahaman masyarakat (Anggraeni, 2011) yang berbeda.

Menjadi penting digarisbawahi, penelitian Jensen dan Meckling (1976) menggunakan sampel penelitian dengan perusahaan yang tersebar. Sementara di Indonesia, sekali lagi, perusahaan-perusahaan besar bersifat terkonsentrasi yang kebanyakan berdasarkan kepemilikan keluarga. Bukti empiris terkait hal ini dihasilkan dari penelitian Claessens, et al. (2000) yang mengungkap bahwa 70\% emiten di Indonesia merupakan perusahaan yang dikendalikan oleh anggota keluarga sendiri. Melangkah empat belas tahun dari data tersebut, Nuritomo (2014) menghasilkan bukti empiris bahwa kepemilikan publik atas perusahaan di Indonesia sejak 2004 mengalami penurunan. Berarti, perusahaan di Indonesia cenderung memiliki pola kepemilikan yang terkonsentrasi.

Hasil penelitian Hapsoro (2007) menyatakan adanya perbedaan persebaran perusahaan-perusahaan di Indonesia dengan yang ada di Amerika Serikat (US) dan Inggris (UK). Di Indonesia, sebagian besar perusahaan terafiliasi oleh keluarga yang sama dalam hal pengendalian sedangkan di US dan UK, struktur kepemilikan perusahaan lebih tersebar.

Hasil penelitian Hapsoro (2007) semacam ini langsung melempar kita beberapa tahun berikutnya ke hasil penelitian Merlyana Lim, seorang akademisi di bidang komunikasi berkebangsaan Indonesia yang kini bekerja di Carleton University. Lim (2012) memaparkan terkait seluruh perusahaan media di Indonesia dengan menyatakan bahwa perusahaan pada industri media, terkonsentrasi sejak era Soeharto di tahun 1998. Media didominasi oleh tiga belas group, dengan satu group yang berstatus publik dan sisanya adalah milik pemodalpemodal besar.

\section{SIMPULAN, KELEMAHAN, DAN SARAN}

Orde baru di bawah tampuk kepemimpinan Soeharto adalah masa-masa pembentukan pola-pikir anti kritik. Kemapamanan status membuat Soeharto nyaman untuk menduduki kursi yang sama, dan selanjutnya mengalirkan keinginan untuk terus bertahan, duduk sebagai 
seorang pemegang kuasa tertinggi negara. Demi melanggengkan kuasa, Soeharto kemudian menjadikan dirinya sebagai seorang 'bapak' yang melindungi negaranya dan dengan demikian harus dihormati dan dipatuhi oleh 'anak-anaknya'.

Hal tersebutlah yang luput diperhatikan oleh Anafiah, et al (2017) dalam artikelnya. Anafiah, et al (2017), juga banyak peneliti akuntansi yang menggunakan teori keagenan dalam artikelnya, abai menganalisis kondisi masyarakat Indonesia yang pola pikirnya banyak dibentuk oleh sistem pada masa orde-baru.

Hubungan bapak-anak yang diwariskan Soeharto sebagai simbol kepatuhan dan ketundukan pada Bapak Tertinggi mengalir dan menetes hingga di berbagai institusi dan lembaga yang ada di Indonesia, termasuk perusahaan. Pada akhirnya, teori keagenan menjadi tidak relevan jika tidak dikunci dengan variabel kontrol yang jelas.

Berangkat dari hasil analisis ulang yang penulis lakukan ini, penulis mengusulkan untuk penelitian selanjutnya terkait teori keagenan agar kiranya mempertimbangkan aspek kepatuhan 'anak' yang merupakan symbol dari pihak manajemen perusahaan dengan 'bapak' sebagai simbol pemegang saham sekaligus pengendali perusahaan. Hanya saja, untuk menyederhanakannya dalam frase variabel penelitian (proxy), penulis belum menemukan frase yang tepat untuk itu. Maka penelitian selanjutnya, dapat pula melihat celah ini untuk diteliti lebih lanjut. Tentu agar kedepannya, riset-riset pasar modal yang menggunakan variabel penelitian berupa teori keagenan dapat menghasilkan riset yang lebih akurat dan valid, yang berangkat dari konteks Indonesia sebagai negara yang punya sejarah dan kondisi sosial serta politik sendiri. Mengutip kalimat Sirimorok (2017), meskipun sudah terbit sekian banyak kritik terhadapnya, pertarungan definisi dan kerangka teoritis berlangsung panjangsebagian setelah menemukan kelemahannya di lapangan, sebagian orang sepertinya masih setia pada bentuk aslinya."

Adapun penulisan artikel ini, hanya karena dipenuhi berbagai kritik terhadap artikel yang dikaji, tidak berarti sedang dalam usaha menjatuhkan dan 'menginjak' peneliti lain. Jika kritik selalu dianggap sebagai tembakan tajam untuk membunuh yang dikritik, maka curahan kritik tidak pernah datang dan perubahan untuk menjadi lebih baik menjadi sulit adanya. Alihalih dianggap sebagai media untuk menjatuhkan, tidakkah kritik lebih bijak dipandang sebagai jalan untuk memperbaiki kesalahan atau menyempurnakan yang masih kurang?

\section{DAFTAR PUSTAKA}


A-Ma'ruf, A.I. 2003. Dekonstruksi Citra Perempuan dalam Sastra: Dari Budaya Lokal hingga Global, KLS, 15(29): 1-12.

Anafiah, V. A., Diyanty, V. dan Wardhani, R. 2017. The Effect Controlling Shareholders and Corporate Govarnance on Audit Quality, Jurnal Akuntansi dan Keuangan Indonesia, 14(1): 1-19.

Anggraeni, M.D. 2012. Agency Theory dalam Perspektif Islam, Jurnal Hukum Islam, 9(2), Desember.

Asechemie, D.P. 1997. African Labour Systems, Maintenance Accounting and Agency Theory, Critical Perspectives on Accounting, 8(4): 373-392.

Ball, R. dan Brown, P. 1968. An Empirical Evaluation of Accounting Income Numbers, Journal of Accounting Research, 6: 159-177.

Bandel, K. 2013. Sastra Nasionalisme Pascakolonialitas. Published by Pustaha Hariara.

Beaver, W. 1968. The Information Content of Anual Earnings Announcements, Journal Accounting Research Supplement,6: 67-92.

Christian, B. dan Mustamu, R.H. 2013. Penerapan Prinsip-prinsip Good Corporate Governance: Studi Deskriptif pada Perusahaan Keluarga Jasa Properti, Jurnal Agora, 1(3): 1133-1140.

Claessens, S., Djankov, S. dan Lang, L.H.P. 2000. The Separation of Ownership and Control in East Asian Corporations, Journal of Financial Economics, 58(1-2,): 81-112.

Damayanti, R.A. 2012. Hubungan Keagenan Era Orde Baru: Eksekutif “Anak Durhaka” yang Mempunyai Kuasa. http://repository.unhas.ac.id. (Diakses tanggal 11 Januari 2017).

Damono, S.D. 2006. Pengarang, Karya Sastra dan Pembaca, Lingua: Jurnal Imu Bahasa dan Sastra, 1(1): 22-37.

Dimnik, T. dan Felton, S. 2006. Accountant Stereotypes in Movies Distributed in North America in Twentieth Century, Accounting, Organizations and Society, 31(2): 129155.

Efferin, S. dan Hopper, T. 2007. Management Control, Culture and Ethnicity in A Chinese Indonesian Company, Accounting, Organizations and Society, 32: 223-262.

Evans, L. 2009. "A Witches' Dance of Numbers": Fictional Portrayals of Business and Accounting Transactions at A Time of Crisis, Accounting, Auditing \& Accountability Journal, 22(2): 169-199.

Evans, L. dan Fraser, I. 2012. The Accountant's Social Background and Stereotype in Popular Culture: The Novels of Alexander Clark Smith, Accounting, Auditing \& Accountability Journal, 25(6): 964-1000.

Freire, P. 2008. Pendidikan Kaum Tertindas. Terjemahan Tim Redaksi LP3ES Indonesia. Published by Pustaka LP3ES Indonesia.

Hapsoro, D. 2007. Pengaruh Struktur Kepemilikan Terhadap Transparasi: Studi Empiris di Pasar Modal Indonesia, Jurnal Akuntansi \& Manajemen, 18(2): 65-85.

Harjito, D.A. dan Singapurwoko, A. 2014. Hubungan Agensi dan Kinerja dalam Tata Kelola Perusahaan Keluarga (Studi Kasus Perusahaan Kecil dan Menengah di Yogyakarta). Seminar Nasional dan Call for Papers Uniba 2014.

Hofstede, G. 1983. National Cultures in Four Dimensions: A Reseacrh-Based Theory of Cultural Differences Among Nations, International Studies of Management \& Organization, 13: 46-74.

Hopper, T., Lassou, P. dan Soobaroyen, T. 2017. Globalisation, Accounting and Developing Countries, Critical Perspectives on Accounting, 43: 125-148.

Jalil, M.H. dan Kadir, F.A.A. 2012. Comprehensive Human Development Through Physical and Spiritual: Studies on the Novel "Tenggelamnya Kapal Van Der Wijck", Procedia- Social dan Behavioral Sciences, 55: 1118-1123. 
James, K. 2008. A Critical Theory and Post-modernist Approach to the Teaching of Accounting Theory, Critical Perspectives on Accounting, 19(5): 643-676.

James, K. 2009. "This is England": Punk Rock's Realist/Idealist Dialectic and Its Implications for Critical Accounting Education, Accounting Forum, 33(2): 127-145.

Jensen, M.C. and W.H. Meckling. 1976. Theory of the Firm: Managerial Behavior, Agency Costs, and Ownership Structure, Journal of Financial Economics, (3): 305-360.

Lim, M. 2012. The League of Thirteen: Media Concentration in Indonesia. Tempe: Participatory Media Lab at Arizona State University.

Prakosa, K.B. 2014. Pengaruh Profitabilitas, Kepemilikan Keluarga dan [']Corporate Governance['] [t]erhadap Penghindaran Pajak di Indonesia. Prosiding, Simposium Nasional Akuntansi 2014.

Putri, M. dan Diyanty, V. 2014. Pengaruh Struktur Kepemilikan dan Mekanisme Corporate Governance terhadap Tingkat Pengungkapan Laporan Keberlanjutan. Prosiding, Simposium Nasional Akuntansi 2014.

Roosa, J. 2008. Dalih Pembunuhan Massal: Gerakan 30 September dan Kudeta Suharto, Cetakan I. Published by Institue Sejarah Sosial Indonesia dan Hasta Mitra.

Sanjaya, I.P.S. 2014. Keluarga [s]ebagai Pemilik Ultimat [d]an Kinerja Perusahaan. Prosiding, Simposium Nasional Akuntansi 2014.

Schuler, Drue K. 1998. Redefining a Certified Public Accounting Firm, Accounting, Organizations and Society, 23(5/6): 549-567.

Shiraishi, S.S. 2009. Pahlawan-pahlawan Belia: Keluarga Indonesia dalam Politik. Diterjemahkan oleh Tim Jakarta-Jakarta. Published by Nalar.

Sirimorok, N. 2008. Laskar Pemimpi: Andrea Hirata, Pembacanya dan Modernisasi Indonesia. Published by INSISTPress.

Sitorus, J. H. E. 2015. Membawa Pancasila dalam Suatu Definisi Akuntansi, Jurnal Akuntansi Multiparadigma, 6(2): 175-340.

Ulupui, I.G.K.A., Utama, S. dan Karnen, K.A. 2014. Pengaruh Kepemilikan Keluarga, Kedekatan Direksi \& Komisaris dengan Pemilik Pengendali terhadap Kompensasi Direksi \& Komisaris Perusahaan di Pasar Modal Indonesia. Prosiding, Simposium Nasional Akuntansi 2014.

Wahyuni, A.S. 2015. Predatory Pricing: Persaingan Harga Minimarket dan Gadde-gadde dalam Metafora Cerpen, Jurnal Akuntansi Multiparadigma, 6(2):237-244.

Wahyuni, A.S. dan Nentry, A. 2017. Ingatan Adalah Media: Studi Etnografi Trik Bertahan dan Pencatatan Kondisi Keuangan Seorang Paggadde-Gadde, Jurnal Akuntansi dan Bisnis, 17(2): 76-87.

Wright, E. O. 2011. Commentary 2: Sociologists and Economists on "the commons". Dalam Bardhan, P. dan Ray, I (Editor). The contested commons: Conversations between economists and antropologists, Oxford: Blackwell Publishing.

Zogning, F. 2017. Agency Theory: A Critical Review, European Journal of Business and Management, 9(2): 1-8. 